\title{
BIOSENSORS
}

\section{AMPEROMETRIC DETECTION OF BIOGENIC AMINES IN CHEESE USING IMMOBILISED DIAMINE OXIDASE}

\author{
D. Compagnone, G. Isoldi, D. Moscone, and G. Palleschi \\ Dipartimento di Scienze e Tecnologie Chimiche, Universitá \\ di Roma Tor Vergata, via della Ricerca Scientifica, \\ 00133 Rome, Italy
}

\begin{abstract}
Diamine oxidase from Lens culinaris has been used for the amperometric detection of biogenic amines in cheese. The enzyme has been immobilised onto polymeric membranes or glass beads and coupled with a Pt based hydrogen peroxide electrode. The resulting enzyme electrode and reactor have been optimised for the response to the six biogenic amines more frequently found in cheese: histamine, tyramine, putrescine, cadaverine, phenylethylamine and tryptamine. Detection limits were found to be in the micromolar range with a linearity up to 3 orders of magnitude. Rejection of the electrochemically active compounds present in cheese was effective by the electropolymerization of 1,4-diaminebenzene onto the $\mathrm{Pt}$ surface. The best performances in terms of sensitivity and selectivity were obtained using the enzyme reactor.
\end{abstract}

Key Words: Biogenic amines; Biosensor; Cheese; Diamine oxidase; Amperometry; FIA. 


\section{INTRODUCTION}

Biogenic amines are ubiquitous in biological matrices, being synthesized in animal and plants and produced by microbial decarboxylation of amino acids. In food, the amount and type of amine content is strongly influenced by the composition, microbial flora and by several technological parameters that allow bacterial growth during storage, as heat treatment, additives, temperature, moisture, ripening and packaging (1). Different HPLC methods have been developed for the detection of biogenic amines in food; most of them are based on spectrophotometric or fluorometric detection following pre-column derivatization with a chromogenic or fluorogenic compound (2-5). More recently, pulsed and square wave amperometric detection has been investigated to avoid derivatization $(6,7)$. These powerful methods of analysis are able to detect each amine in the sample and are very accurate; however, they do not appear suitable for the rapid on-site measurement of biogenic amines in food.

Electrochemical biosensors or bioreactors for the detection of biogenic amines based on the enzymes monoamine oxidase, diamine oxidase and putrescine oxidase have been also reported in the literature (8-13). Due to the broad selectivity of these enzymes the resulting sensors give an index of the total amount of biogenic amines, that is, however, useful for the assessment of the storage conditions or quality of foods. The attention has been mainly focussed on the estimation of fish quality $(8,9)$ and chicken spoilage (11).

In cheese, during ripening, casein is slowly degraded by proteolitic enzymes; this leads to an increase of free aminoacids susceptible to decarboxylation by bacterial decarboxylases (14). The most relevant biogenic amines that are found in cheese (and their precursors) are the following: histamine (histidine), tyramine (tyrosine), putrescine (ornithine), cadaverine (lysine), tryptamine (tryptophan) and phenylethylamine (phenylalanine). Histamine is certainly the most relevant biogenic amine in cheese from a toxicological point of view, followed by tyramine (14). Histamine and tyramine toxicity is increased by the presence of other amines as putrescine, cadaverine and phenylethylamine, because of their inhibitory effect on intestinal enzymes (diamine oxidase and histamine- $\mathrm{N}$-methyl-trasferase) (14). Because of this "enhancing" effect it is very difficult to establish which is the minimum amount of histamine in cheese that can be considered toxic. Besides the toxicological aspects, the content of biogenic amines in cheese has been proposed both as hygienic and technological quality control parameter during the manufacturing and storage of the product $(15-17)$. 
In this paper we report the development of an electrochemical biosensor and a bioreactor for the determination of biogenic amines in cheese using immobilised diamine oxidase from Lens Culinaris and hydrogen peroxide detection. Both systems have been optimized and analytically characterized in terms of sensitivity and selectivity. Different strategies for the rejection of electrochemical interferences present in cheese samples have been evaluated. The developed systems appear suitable for the rapid detection of biogenic amines in cheese.

\section{MATERIALS AND METHODS}

\section{Reagents and Apparatus}

Diamine oxidase (DAO; $73 \mathrm{U} / \mathrm{mg}$ protein) was purified from lens seedlings (Lens culinaris) grown 8-10 days in the dark at $25^{\circ} \mathrm{C}$ following the procedure of Padiglia et al. (18). Histamine, tyramine, cadaverine, putrescine, phenylethylamine, tryptamine and all other reagents were from Sigma Chemical Co., St. Louis, MO, USA. Stock amines solutions $(0.1 \mathrm{~mol} / \mathrm{L})$ were freshly prepared every $2-4$ days in water and stored at $4{ }^{\circ} \mathrm{C}$ when not in use.

Cellulose acetate membranes, 100 Da cut-off, were prepared according to a procedure reported in the literature (19). Polycarbonate membranes, $0.03 \mu \mathrm{m}$ porosity, were from Nucleopore, Pleasanton, CA, USA. Immobilon AV was from Millipore (Bedford, MA, USA) while nylon net, $60 \mathrm{mesh} \mathrm{cm}^{2}$, $100 \mu \mathrm{m}$ thickness, was obtained from a local shop.

The $\mathrm{H}_{2} \mathrm{O}_{2}$ sensor consisted of a platinum electrode polarized at $+650 \mathrm{mV}$ vs. a built-in $\mathrm{Ag} / \mathrm{AgCl}$ reference electrode (Universal Sensors, Metairie, LA, USA). The current output was monitored with a ABD from Universal Sensors and recorded with a Linseis (Selb, Germany) mod. L6512 recorder. The FIA system was assembled using a flow-through cell (Universal Sensors) and a model 5020 Rheodyne (USA) injection valve connected with a Gilson (France) peristaltic pump. A 433A polarograhic system from Amel (Italy) was used for electropolymerization experiments.

\section{Procedures}

Assembling of the Enzymatic Probe and Reactor

DAO was immobilised on preactivated Immobilon AV membranes by placing $20 \mu \mathrm{L}$ of enzymatic solution onto $1 \mathrm{~cm}^{2}$ of the membrane and allowing the reaction to occur for $30 \mathrm{~min}$ at room temperature. Before use the 
membrane was washed with $0.1 \mathrm{~mol} / \mathrm{L}$ phosphate buffer containing $0.1 \mathrm{~mol} / \mathrm{L}$ glycine. Immobilization on nylon net (as physical support) using glutaraldehyde was performed as follows: $16 \mu \mathrm{L}$ of enzymatic solution was mixed with $4 \mu \mathrm{L}$ of $0.25 \%$ glutaraldehyde, immediately placed on the nylon membrane, allowed to dry for $1 \mathrm{~h}$ and extensively washed with $0.1 \mathrm{~mol} / \mathrm{L}$ glycine to eliminate excess glutaraldehyde.

The biosensor was assembled by placing the polycarbonate membrane externally and the enzymatic membrane sandwiched between the cellulose acetate membrane (in contact with the electrode surface) and the polycarbonate. The membranes where secured onto the electrode jacket provided by the manufacturer with an O-ring; the jacket was then filled with $0.1 \mathrm{M} \mathrm{KCl}$ and mounted on the probe until the $\mathrm{Pt}$ surface was in tight contact with the cellulose acetate membrane.

For the realization of the enzymatic reactor, DAO was immobilized on controlled pore glass beads (aminopropyl-CPG pore size $700 \AA$, particle size $80-120$ mesh; Sigma). The beads were first activated with $2.5 \%$ glutaraldehyde in $0.1 \mathrm{M}$ phosphate buffer $\mathrm{pH} 7.0$ for $1 \mathrm{~h}$, then washed with water and let to react with the enzyme solution $(200 \mu \mathrm{L})$ overnight at $4{ }^{\circ} \mathrm{C}$. The glass beads were then packed into a tygon tube closed at the distal end by glued nylon net. After packing, the second end was closed in the same way.

\section{Electrochemically Modified Electrodes}

The metallization of glassy carbon using a rhodium/ruthenium mixture has been obtained as reported by O'Connell et al. (20). After cleaning with alumina and by cyclic voltammetry in water $(0.9-1.5 \mathrm{~V}$ at $50 \mathrm{mV} / \mathrm{s}$ for $5 \mathrm{~min})$, the electrode has been cycled between -0.65 and $+1.00 \mathrm{~V}$ (vs. SCE) in a oxygen-free solution of $100 \mathrm{ppm}$ rhodium and $100 \mathrm{ppm}$ ruthenium $\mathrm{pH} 2.5$. 25 scans have been run at a scan rate of $50 \mathrm{mV} / \mathrm{s}$.

Electropolymerisation of 1,4-diamminebenzene (1,4-DAB), 1,2-diamminebenzene (1,2 DAB), 4,4'-dihydroxybenzophenone (4,4'-DHB) and resorcinol onto Pt electrodes has been obtained following the procedure of Curulli et al. (21). After cleaning with alumina and by cyclic voltammetry in $0.5 \mathrm{M} \mathrm{H}_{2} \mathrm{SO}_{4}(-0.2-1.2 \mathrm{~V}$ at $20 \mathrm{mV} / \mathrm{s})$, the electrode underwent 30 cycles between 0 and $0.8 \mathrm{~V}$ at scan rate of $2 \mathrm{mV} / \mathrm{s}$ in the oxygen-free monomer solution. Concentration of the monomer was $5 \mathrm{mmol} / \mathrm{L}$ dissolved in $0.1 \mathrm{M}$ phosphate buffer $\mathrm{pH} 6.5$ for 1,2-DAB and 1,4-DAB and in $0.1 \mathrm{M}$ phosphate buffer $\mathrm{pH} 8.0$ for $4,4^{\prime}-\mathrm{DHB}$ and resorcinol. 
Samples

All cheese samples were obtained at local stores in Rome. The cheese exctracts were obtained by homogenising $8 \mathrm{~g}$ of cheese in $16 \mathrm{~mL} 0.1 \mathrm{M} \mathrm{HCl}$. The resulting mixture was filtered on Whatman paper and the solution diluted as appropriate with the working buffer just before the analysis.

\section{RESULTS AND DISCUSSION}

The aim of the present work was to settle a flow injection system for monitoring biogenic amines content in cheese. The enzyme diamine oxidase (DAO) was selected because of the broad substrate specificity; in fact, the DAO catalyses the oxidative deamination of several biogenic amines to aldehydes with $\mathrm{H}_{2} \mathrm{O}_{2}$ production. The generic enzymatic reaction is the following:

$$
\mathrm{R}-\mathrm{CH}_{2}-\mathrm{NH}_{2}+\mathrm{O}_{2}+\mathrm{H}_{2} \mathrm{O} \rightarrow \mathrm{R}-\mathrm{CHO}+\mathrm{H}_{2} \mathrm{O}_{2}+\mathrm{NH}_{3}
$$

$\mathrm{H}_{2} \mathrm{O}_{2}$ has been detected at a $\mathrm{Pt}$ working electrode polarized at $+650 \mathrm{mV} v$ s. a $\mathrm{Ag} / \mathrm{AgCl}$ reference electrode.

\section{DAO Based Enzyme Electrode}

Immobilization of DAO onto a membrane was attained through the free amino groups of the enzyme using 2 different procedures: direct Immobilization onto a preactivated membrane (Immobilon AV) and cross-linking with glutaraldehyde using a nylon membrane as physical support. Both procedures were successful for the realization of the biogenic amine enzyme electrode. The second procedure was selected for the final assembling of the biosensor because of the better sensitivity (i.e. $\approx 40 \%$ of the response of the nylon-based membrane was obtained using the Immobilon membrane for all the amines). No improvement in sensitivity was observed adding BSA to the reaction mixture (data not shown). The enzyme electrode was then inserted in the electrochemical flow-through cell and all the experimental parameters optimised. The selected FIA conditions were: $0.1 \mathrm{M}$ phosphate $\mathrm{pH} 8.0$ as working buffer pumped at a flow rate of $0.5 \mathrm{~mL} / \mathrm{min}$ and connected with an injection loop of $100 \mu \mathrm{L}$ volume. The calibration curves for the six biogenic amines commonly present in cheese are reported in Fig. 1. The analytical behavior for each of the amine tested is reported in detail in Table 1 . The highest response was obtained for putrescine and cadaverine, while the reactions involving the other monoamines 


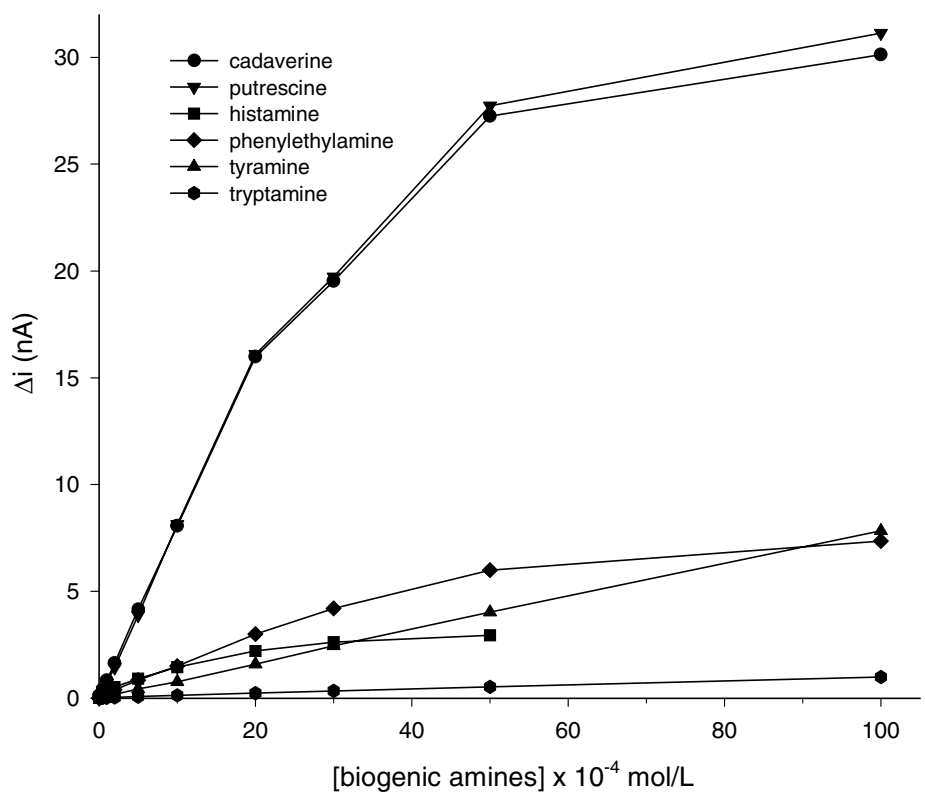

Figure 1. Calibration curves for the biogenic amines obtained with the DAO based enzyme electrode.

Table 1. Analytical Behaviour of the DAO Based Enzyme Electrode

\begin{tabular}{lcccc}
\hline & $\begin{array}{c}\text { Sensitivity } \\
(\mathrm{nA} / \mathrm{mmol})\end{array}$ & $\begin{array}{c}\text { Linearity Range } \\
(\mathrm{mol} / \mathrm{L})\end{array}$ & $\begin{array}{c}\text { Detection Limit } \\
(\mathrm{mol} / \mathrm{L})\end{array}$ & $\begin{array}{c}\text { RSD }(\%) \\
\left(5 \times 10^{-5} \mathrm{~mol} / \mathrm{L}\right)\end{array}$ \\
\hline Putrescine & 8.14 & $5 \times 10^{-6}-2 \times 10^{-3}$ & $10^{-6}$ & 2.2 \\
Cadaverine & 8.05 & $5 \times 10^{-6}-2 \times 10^{-3}$ & $10^{-6}$ & 1.4 \\
Phenylethylamine & 1.50 & $5 \times 10^{-6}-2 \times 10^{-3}$ & $10^{-6}$ & 3.1 \\
Tryptamine & 0.13 & $2 \times 10^{-5}-5 \times 10^{-3}$ & $10^{-5}$ & 6.6 \\
Histamine & 1.45 & $10^{-5}-10^{-4}$ & $5 \times 10^{-6}$ & 2.8 \\
Tyramine & 0.76 & $10^{-5}-2 \times 10^{-3}$ & $5 \times 10^{-6}$ & 3.5 \\
\hline
\end{tabular}

were slower. Linearity range was in each case very wide (3 orders of magnitude) with good reproducibility (1-5\% RSD). The electrode, stored in phosphate buffer at $4{ }^{\circ} \mathrm{C}$, exhibited a decrease of $60 \%$ of the initial activity after 1 month. 


\section{Interference Studies}

Analysis of the biogenic amine content of some cheese samples (Parmigiano Reggiano, Grana Padano and Pecorino Romano) were carried out with the developed FIA system. A recovery study, run by addition of $10^{-5} \mathrm{~mol} / \mathrm{L}$ of histamine to the acidic extracts diluted 1:20 in the working buffer, gave good recovery values (from 90 to $96 \%$ ). However, a spurious signal (ranging from 10 to $30 \mathrm{pA}$ ) was obtained testing the samples with a "blank" enzyme electrode in which the enzyme was replaced by an inert protein (BSA). This effect was attributed to the presence of low molecular weight compounds that are oxidised at the electrode surface; these can be produced by the microrganisms used for the production of cheese or by side reactions (Maillard reaction) occurring spontaneously in milk and milk products (22).

Improvement of the selectivity of the electrochemical response for $\mathrm{H}_{2} \mathrm{O}_{2}$ was attempted using metallisation of a glassy carbon electrode and modification of the platinum electrode by electropolymerization of nonconducting polymers. Glassy carbon rhodium/rhutenium electrodes were prepared as described in the materials and methods section. These probes allow the sensitive detection of $\mathrm{H}_{2} \mathrm{O}_{2}$ at low potentials (via reduction) thus reducing the signal of the interferents 1 (20). The best signal to noise ratio for the reduction of $\mathrm{H}_{2} \mathrm{O}_{2}$ was obtained at an applied potential of $+200 \mathrm{mV}$ vs. $\mathrm{Ag} / \mathrm{AgCl}$, allowing the detection of $10^{-7} \mathrm{~mol} / \mathrm{L}$ of $\mathrm{H}_{2} \mathrm{O}_{2}$ with a linear range up to $10^{-4} \mathrm{~mol} / \mathrm{L}$. The selectivity of the probe was tested with ascorbic acid as a model interfering compound. The response of the probe to ascorbic acid was strongly reduced when the concentration was in the $\mathrm{mmol} / \mathrm{L}$ range; however at very low levels (below $10^{-5} \mathrm{~mol} / \mathrm{L}$ ) the ascorbic acid response was $90 \%$ of the $\mathrm{H}_{2} \mathrm{O}_{2}$ signal (Fig.2). Improved selectivity was obtained using electropolymerization of non conductive polymers onto the Pt surface. Four different polymers were tested, prepared from the corresponding monomers (1,2-DAB, 1,4-DAB, 4,4'-DHB, resorcinol) as described in the materials and methods. Calibration data for $\mathrm{H}_{2} \mathrm{O}_{2}$ and ascorbic acid are reported in Fig.3. It is evident that the non-conducting polymers improved the selectivity of the probe for ascorbic acid in the entire range of concentrations tested, the most effective being the diaminebenzene polymers. The electrode modified by electropolymerisation of 1,4-DAB was selected because of the best performances with cheese samples. Table 2 reports the reduction of the interfering signal obtained with this electrode versus the cellulose acetate electrode for the above mentioned cheese samples. The use of 1,4-DAB modified electrode reduced the spurious signal for all the samples tested. 


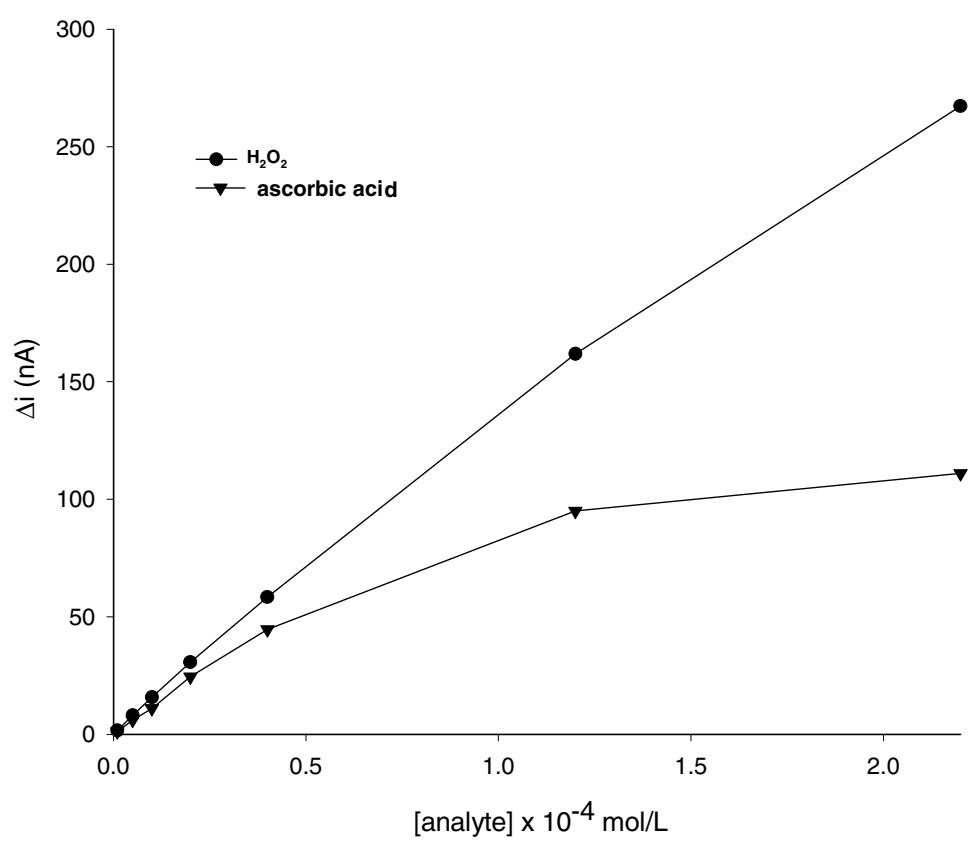

Figure 2. Calibration curves for ascorbic acid and $\mathrm{H}_{2} \mathrm{O}_{2}$ obtained with the Rhodium/ruthenium metallised glassy carbon electrode polarised at $+200 \mathrm{mV}$ vs. $\mathrm{Ag} / \mathrm{AgCl}$.

\section{DAO Based Enzyme Reactor}

An enzymatic reactor was prepared by covalent immobilisation of DAO onto aminopropyl glass beads; the reactor was placed between the injection valve and the electrochemical cell, equipped with the 1,4-DAB modified electrode. The system was expected to have better performances of the DAO enzyme electrode. In fact, the longer exposure of the substrates to the immobilised enzyme led to an improved efficiency of the reaction (conversion rate) and then to an increase in sensitivity. The calibration curves for the six biogenic amines tested are shown in Fig.4, while the analitycal behaviour of the reactor based system is summarised in Table 3. A more homogeneous response was also obtained with this system. Four of the six amines gave similar sensitivity, the highest response being for histamine and the lowest for putrescine ( $80 \%$ of maximum response). The signal for tryptamine, that was $2 \%$ of the maximum (putrescine) with the DAO 


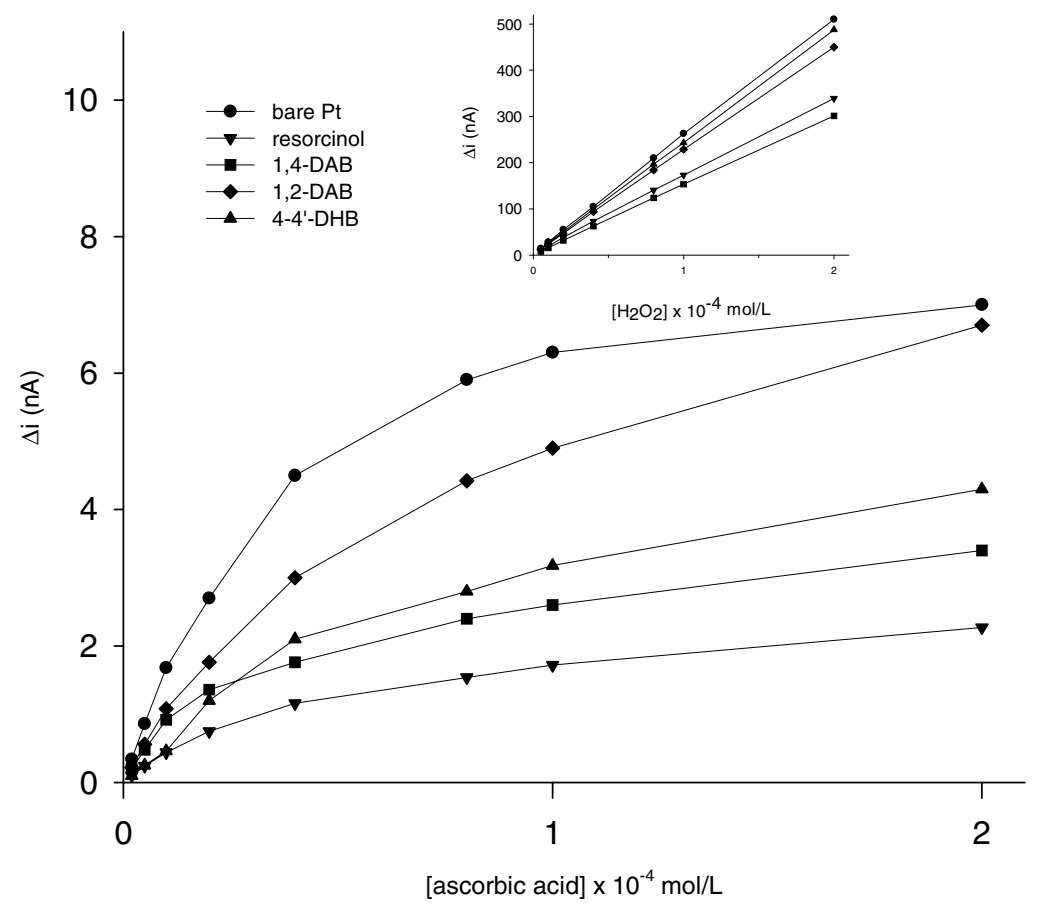

Figure 3. Amperometric response for ascorbic acid and $\mathrm{H}_{2} \mathrm{O}_{2}$ (inset) for a bare and non-conducting polymers modified Pt electrode polarised at $+650 \mathrm{mV}$ vs. $\mathrm{Ag} / \mathrm{AgCl}$.

Table 2. Current Output of Cellulose Acetate and the 1,4-DAB Electropolymerised Pt Working Electrode with 3 Cheese Samples Diluted 1:20 in the Working Buffer After Extraction

\begin{tabular}{lccccc}
\hline & \multicolumn{2}{c}{ Cellulose Acetate } & & \multicolumn{2}{c}{$1,4-\mathrm{DAB}$} \\
\cline { 2 - 3 } \cline { 5 - 6 } & Blank $^{\mathrm{a}}$ & $\mathrm{DAO}^{\mathrm{b}}$ & & Blank $^{\mathrm{a}}$ & DAO $^{\mathrm{b}}(\mathrm{pA})$ \\
\hline Parmigiano Reggiano & $19 \pm 2$ & $119 \pm 8$ & & $9 \pm 2$ & $113 \pm 5$ \\
Grana Padano & $13 \pm 1$ & $163 \pm 5$ & & $7 \pm 1$ & $175 \pm 6$ \\
Pecorino Romano & $27 \pm 2$ & $48 \pm 3$ & & $3 \pm 1$ & $50 \pm 3$ \\
\hline
\end{tabular}

${ }^{\mathrm{a}}$ BSA-glutaraldehyde on nylon net; ${ }^{\mathrm{b}}$ DAO-glutaraldehyde on nylon net.

based enzyme electrode, resulted to be raised up to $32 \%$ of the maximum signal (histamine) with the DAO based reactor.

Moreover, the higher current output increased the analytical signal/ interference ratio allowing the measurement of biogenic amine content in 


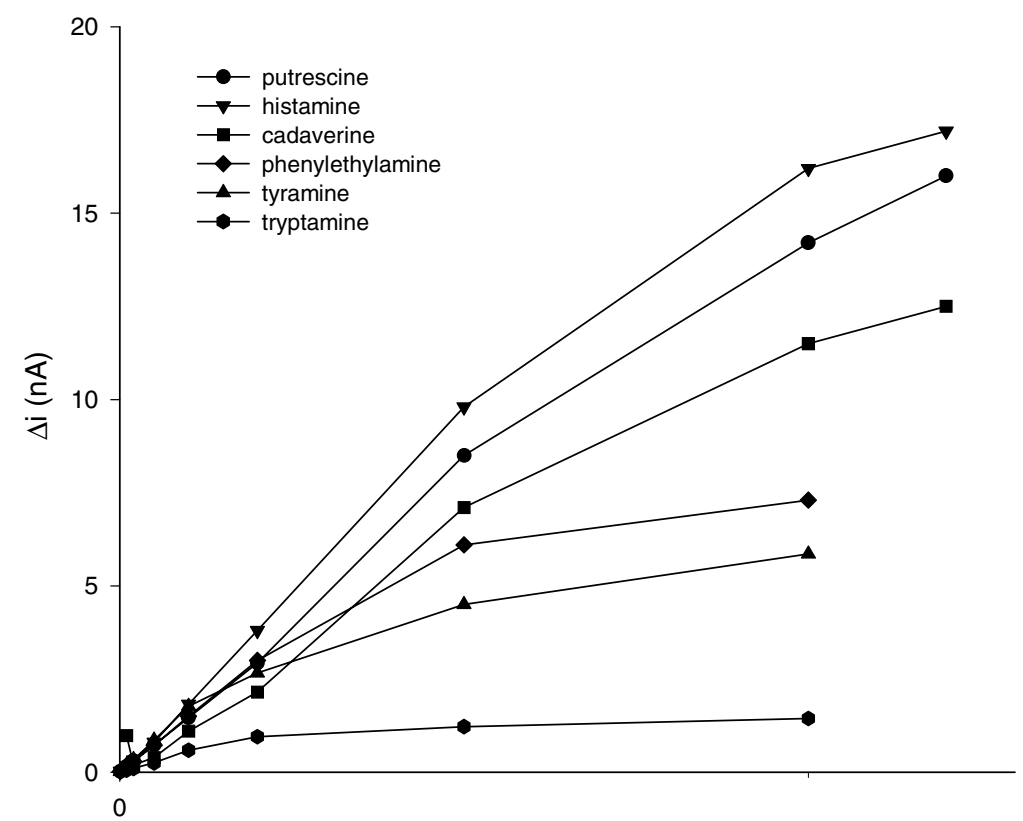

[biogenic amines] $\times 10^{-4} \mathrm{~mol} / \mathrm{L}$

Figure 4. Calibration curves for the biogenic amines obtained with the DAO based enzyme reactor coupled with the $1,4-\mathrm{DAB}$ modified $\mathrm{H}_{2} \mathrm{O}_{2}$ probe.

Table 3. Analytical Behaviour of the DAO Based Enzyme Reactor

\begin{tabular}{lcccc}
\hline & $\begin{array}{c}\text { Sensitivity } \\
(\mathrm{nA} / \mathrm{mmol})\end{array}$ & $\begin{array}{c}\text { Linearity Range } \\
(\mathrm{mol} / \mathrm{L})\end{array}$ & $\begin{array}{c}\text { Detection Limit } \\
(\mathrm{mol} / \mathrm{L})\end{array}$ & $\begin{array}{c}\text { RSD }(\%) \\
5 \times 10^{-5} \mathrm{~mol} / \mathrm{L}\end{array}$ \\
\hline Histamine & 18.2 & $10^{-6}-10^{-3}$ & $5 \times 10^{-7}$ & 1.0 \\
Tyramine & 17.0 & $10^{-6}-10^{-4}$ & $5 \times 10^{-7}$ & 2.8 \\
Putrescine & 14.6 & $10^{-6}-10^{-3}$ & $5 \times 10^{-7}$ & 0.6 \\
Phenylethylamine & 15.0 & $10^{-6}-2 \times 10^{-4}$ & $5 \times 10^{-7}$ & 1.8 \\
Cadaverine & 11.0 & $5 \times 10^{-6}-10^{-3}$ & $10^{-6}$ & 2.4 \\
Tryptamine & 5.9 & $5 \times 10^{-6}-2 \times 10^{-4}$ & $2 \times 10^{-6}$ & 3.0 \\
\hline
\end{tabular}

cheese at a 1:100 dilution of the acidic homogenate. In fact, the spurious signal for all the cheese samples analysed with the reactor was below $0.5 \%$ of the analytical signal. Table 4 reports the determination of the amine content (expressed as $\mathrm{mg} / \mathrm{g}$ of histamine equivalents) and the recovery 
Table 4. Recovery Study of Biogenic Amines in 6 Cheese Samples Diluted 1:100 in Working Buffer After Extraction. Biogenic Amines Content Is Expressed as Histamine Equivalents

\begin{tabular}{|c|c|c|c|c|c|c|}
\hline & $\begin{array}{l}\text { Concentration } \\
\left(\mathrm{mol} / \mathrm{L} \times 10^{-5}\right)\end{array}$ & $\begin{array}{c}\text { Histamine } \\
\text { Added } \\
\left(\mathrm{mol} / \mathrm{L} \times 10^{-5}\right)\end{array}$ & $\begin{array}{c}\text { Expected } \\
\left(\mathrm{mol} / \mathrm{L} \times 10^{-5}\right)\end{array}$ & $\begin{array}{c}\text { Found } \\
\left(\mathrm{mol} / \mathrm{L} \times 10^{-5}\right)\end{array}$ & $\begin{array}{c}\text { Recovery } \\
(\%)\end{array}$ & $\begin{array}{c}\text { Biogenic } \\
\text { Amines } \\
(\mathrm{mg} / \mathrm{g})\end{array}$ \\
\hline $\begin{array}{l}\text { Parmigiano } \\
\text { reggiano } \\
\text { ( } 24 \text { months) }\end{array}$ & 1.44 & 1 & 2.44 & 2.43 & 100 & 0.35 \\
\hline $\begin{array}{l}\text { pecorino } \\
\text { romano } \\
\text { (18 months) }\end{array}$ & 0.77 & 1 & 1.77 & 1.86 & 105 & 0.28 \\
\hline $\begin{array}{l}\text { pecorino } \\
\text { romano } \\
\text { (12 months) }\end{array}$ & 1.00 & 1 & 2.00 & 1.95 & 98 & 0.38 \\
\hline $\begin{array}{l}\text { pecorino } \\
\text { romano } \\
(6 \text { months })\end{array}$ & 0.07 & 1 & 1.07 & 1.01 & 94 & 0.02 \\
\hline groviera & 0.15 & 1 & 1.15 & 1.24 & 107 & 0.04 \\
\hline gorgonzola & 2.11 & 1 & 3.11 & 3.16 & 102 & 0.65 \\
\hline
\end{tabular}

study of 6 samples of cheese. Recovery values ranged from 94 to $107 \%$ and the amount of biogenic amines detected was of the same order of magnitude of that reported in the literature.

The storage lifetime of the enzyme reactor was three months in phosphate buffer at $4{ }^{\circ} \mathrm{C}(20 \%$ of the initial activity). Operational lifetime was calculated to be 300 samples. An attempt to restore the activity of the reactor was made by overnight storage at $4^{\circ} \mathrm{C}$ in a saturated $\mathrm{CuCl}$ solution. In fact, the DAO purified from lentil is a dimer composed of 2 identical subunits containing one copper atom as cofactor. The presence of these metal cofactors seems to have a structural and functional value. The activity of the reactor was partially restored $(60 \%$ of the initial) after incubation with $\mathrm{CuCl}$; however, the selectivity pattern for the amines was sligthly different. Further investigations are needed to understand the phenomenon.

\section{CONCLUSIONS}

The detection of biogenic amines in cheese has been obtained using immobilized diamine oxidase from lentil and hydrogen peroxide detection. 
An enzyme electrode and a reactor have been prepared and assembled, analytically characterized and tested with cheese samples in FIA. The best performances in terms of sensitivity and selectivity have been obtained using the enzyme electrode coupled with a Pt working electrode modified by electropolymerisation of 1,4-diaminebenzene. The developed system appears suitable for biogenic amine content monitoring during ripening and storage of cheese.

\section{ACKNOWLEDGMENTS}

Authors wish to thank the CNR target project MADESS II, subproject Sensors, for financial support.

\section{REFERENCES}

1. Halasz, A.; Barath, A.; Sarkadi, L.S.; Holzapfel, W. " Biogenic amines and their production by microorganisms in food" Trends in Food Sci. and Technol., 1994, 5, 42-49.

2. Hurst, W. J. "A review of HPLC methods for the determination of selected biogenic amines in food" J. Liquid Chromatogr., 1990, 13, 1-23.

3. Gow-Chin Yen, Chiu-Luan Hsieh "Simultaneous analysis of biogenic amines in canned fish by HPLC" J. Food Sci., 1991, 158-160.

4. Eerola, S.; Hinkkanen, R.; Lindfors, E.; Hievi, T. (1993) "Liquid chromatographic determination of biogenic amines in dry sausages" $J$. AOAC Int., 1993, 3, 575-577.

5. Kirschbaum, J.; Meier A.; Bruckner, H.; "Determination of biogenic amines in fermented beverages and vinegars by pre-column derivation with p-Nitrobenzylloxycaerbonyl chloride (PNZ-Cl) and Reversed phase-LC" chromatographia, 1999, 49, 117-124.

6. Draisci, R.; Cavalli, S.; Lucentini, L.; Stacchini, A. "Ion exchange separation and pulsed amperometric detection for the determination of biogenic amines in fish products" Chromatographia, 1993, 35, 584-590.

7. Hoekstra, J. C.; Jonhson, D. C. "Waveform optimisation for integrated square wave detection of biogenic amines following their liquid chromatographic separation" Anal. Chim. Acta, 1999, 390, 45-54.

8. Chemnitius, G. C.; Bilitewski, U. "Development of screen-printed electrodes for the estimation of fish quality" Sensors and Actuators, 1996, B32, 107-113. 
9. Draisci, R.; Volpe, G.; Lucentini, L.; Cecilia, A.; Federico, R.; Palleschi, G. "Determination of biogenic amines with an electrochemical biosensor and its application to salted anchovies" Food Chem., 1998, 62, 225-232.

10. Tombelli, S.; Mascini, M. "Electrochemical biosensors for biogenic amines: a comparison between different approaches" Anal Chim. Acta, 358, 277-284.

11. Okuma. H.; Okazaki, W.; Usami, R.; Horikoshi, K. "Development of the enzyme reactor system with amperometric detection and application to estimation of the incipient stage of spoilage of chicken" Anal.Chim. Acta, 2000, 411, 37-43.

12. Carsol, M. A.; Mascini, M. "Diamine oxidase and putrescine oxidase immobilized reactors in flow injection analysis: a comparison in substrate specificity" Talanta, 1999, 50, 141-148.

13. Wimmerova, M.; Macholan, L. "Sensitive amperometric biosensor for the determination of biogenic and synthetic amines using pea seedlings amine oxidase: a novel approach for enzyme immobilisation" Bios. \& Bioel, 1999, 14, 695-702.

14. Stratton, J. E.; Hutkins, R. W.; Taylor, S. L. "Biogenic amines in cheese and other fermented foods: a review" J. Food Protec., 1991, $54,460-470$.

15. Lanza, C. M.; Russo C.; Tomaselli, F. "Ammine biogene come parametro di qualitá igienica nei formaggi siciliani" Il latte, 1994, 4, 390-393.

16. Martelli, A.; Arlorio, M.; Tourn, M.L. "Determination of amines and precursor aminoacids in gorgonzola cheese by ion-pair HPLC without derivatization" La rivista di Scienza dell'Alimentazione, 1993, 22, 261-270.

17. Cerruti, G.; Cecchi L.; Branca, M.; Manera, E.; Paita F. "Biogenesi di ammine nella conservazione dei formaggi" La rivista di Scienza dell'Alimentazione, 1994, 23, 441-452.

18. Padiglia, A.; Cogoni, A.; Floris, G. "Characterization of amine oxidase from pisum, lens, lathirus and cicer" Phytochemistry, 1991, 30, 3895-3897.

19. Mascini, M.; Mazzei, F. "Amperometric sensor for pyruvate using immobilised pyruvate oxidase" Anal. Chim. Acta, 1987, 92, 9-16.

20. O'Connell, P. J.; O’Sullivan, C.K.; Guilbault, G. G. "Electrochemical metallisation of carbon electrodes" Anal. Chim. Acta, 1998, 373, 261-270.

21. Curulli, A.; Carelli, I.; Trischitta, O.; Palleschi, G. "Assembling and evaluation of new dehydrogenase enzyme electrode probes obtained by 
electropolymerization of aminobenzene isomers and PQQ on gold, platinum and carbon electrodes" Biosen. Bioel., 1997, 12, 1043-1055.

22. van Boeckel, M. A. J. S. "Effect of heating of Maillard reactions in milk" Food Chem., 1998, 62, 403-414.

Received December 1, 2000

Accepted February 1, 2001 